\title{
Geomorphological Aspects of the Human Impact in the Alpine Area of Southern Carpathians (Romania)
}

\author{
Petru Urdea, Marcel Törok-Oance, Mircea Ardelean, \\ Florin Vuia, Mircea Voiculescu
}

\begin{abstract}
This paper deals with some human geomorphological aspects concerning the impact in the alpine area of the Southern Carpathians (Transylvanian Alps). After field investigations and taking into account the major effects of road building, military and mining activities, pasture and tourism activities in the geomorphological landscape we have the possibilities to present a distinct image of some relevant detailed situations. In our opinion the building of roads in the alpine area is by far the most dangerous way of intervention in the geomorphological landscape of the alpine area of the Southern Carpathians. The construction of these roads has altered the profile of the slope and new scarps have appeared. This situation associated with the vibrations induced by the traffic favours frost weathering, rock falling and rolling, coupled with the emergence of specific deposits and landforms (talus cones and scree) and, of course, with vertical and gully erosion, which is very typical of the area of soft rocks and soils.
\end{abstract}

Key words: human impact, geomorphological processes, gullying, land degradation, Southern Carpathians, Romania.

\section{Geomorfološki aspekt antropogenih utjecaja u gorskom području Južnih Karpata (Rumunjska)}

U članku se analiziraju geomorfološki aspekti antropogenog utjecaja u planinskom području Južnih Karpata (Transilvanske Alpe). Nakon terenskih istraživanja i razmatranja glavnih učinaka gradnje prometnica, vojnih i rudarskih djelatnosti, stočarstva i turizma u krajoliku, iscrpno su opisani konkretni slučajevi. Prema autorovu mišljenju, gradnja prometnica u planinskim područjima daleko je najopasnija intervencija za planinski geomorfološki krajolik Južnih Karpata. Ona je izmijenila profil padina i stvorila nove strmce. Takvo stanje, povezano s vibracijama od prometa, mehaničkim trošenjem stijena, osipanjem i odronima na padinama, dovelo je do akumulacije specifičnih taloga i nastanka reljefnih oblika te pojačane erozije tipične za područja mekog tla i stijena.

Ključne riječi: antropogeni utjecaj, geomorfološki procesi, jaruženje, degradacija tla, Južni Karpati, Rumunjska 


\section{INTRODUCTION}

The Carpathian arch is the vertebral column of the entire relief of Romania. Situated in a millenary oicumenic space, this area was permanently of primordially economic interest due to ore resources, forests and pastures. Throughout the history, under a minor human pressure, the landscape has remained naturally predominant on the inside, evincing a relative harmony between human society and mountain nature.

We want to specify the fact that in the present article we include the entire alpine area lying above the timberline.

\section{THE STUDY AREA}

The Southern Carpathians, or the Transylvanian Alps, lie between the Prahova Valley in the East, Timiş-Cerna Passage in the west, the Transylvanian Basin in the north and the Getic and Curvature Subcarpathians in the south (Fig. 1). This mountain range makes up the most massive and highest part of the Romanian Carpathians, having 14 peaks above $2500 \mathrm{~m}$ and a maximum elevation of $2544 \mathrm{~m}$ in Moldoveanu Peak (Făgăraş Mountains). $10 \%$ of the mountain areas lies above $2000 \mathrm{~m}$.

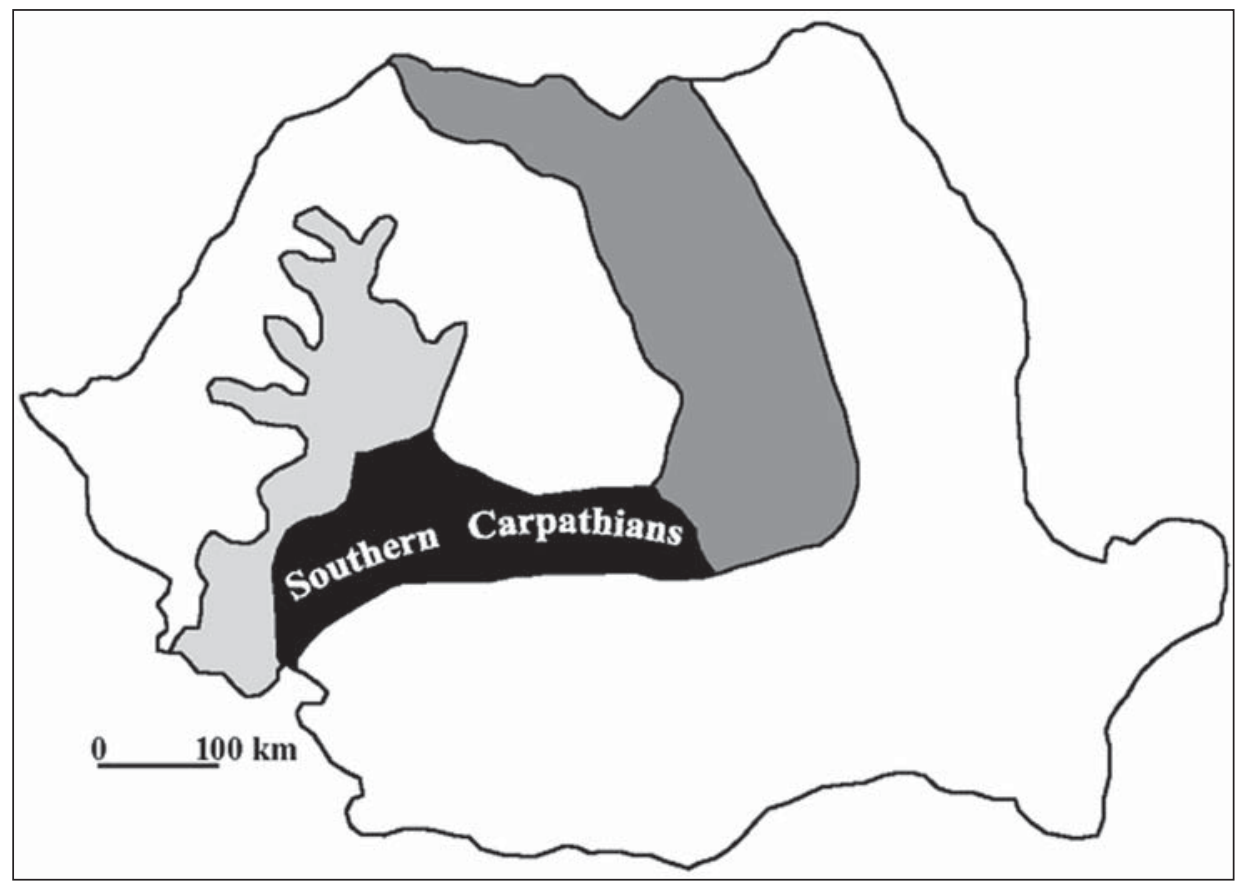

Fig. 1 Geographical location of Southern Carpathians within Romania Sl. 1. Geografski položaj Južnih Karpata u Rumunjskoj 
The Pleistocene glaciers reached elevations of 1100-1200 m during their maximum extension, and carved an extensive suite of alpine glacial landforms with sharp peaks and ridges, with cirques, steep slopes and U-shaped valleys (Urdea, 2000). The interaction of paraglacial processes and periglacial phenomena produced a variety of periglacial forms (rockglaciers, talus cones and scree slopes, block fields, rock streams, cryoplanation terraces, solifluction forms; Urdea, 1992). The most part of the Southern Carpathians is composed of crystalline rock and magmatic bodies of granites and granodiorites, especially in the Retezat, Parâng and Țarcu Mountains. In the Bucegi Mountains the conglomerates and sandstones are characteristic.

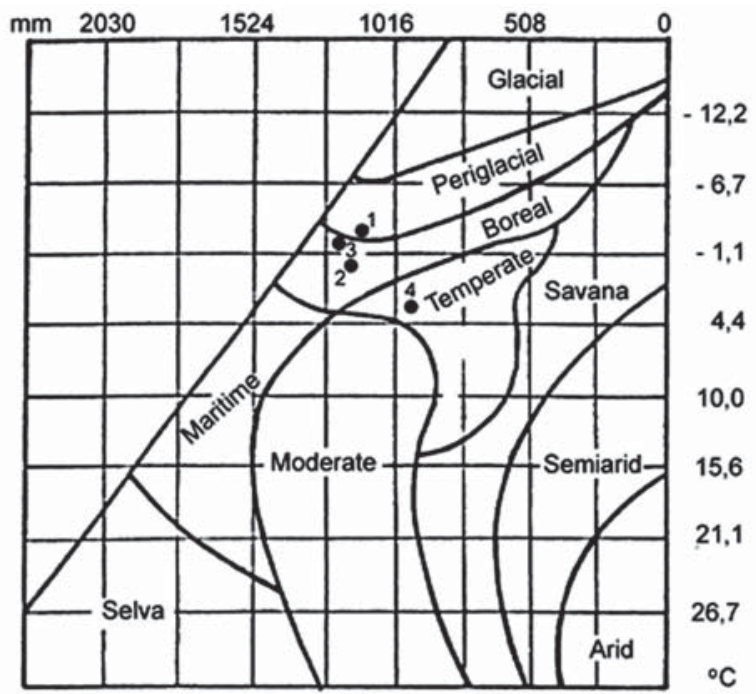

1. Omu Peak St. (2505 m); 2. Tarcu St. (2180 m);

3. Bâlea - Lake St. (2038 m); 4. Cozia St. (1577 m)

Fig. 2 Morphoclimatic systems in the Peltier diagramme

Sl. 2. Morfoklimatski sustavi na Peltierovom dijagramu

The climatic conditions specific for the high zone of the Southern Carpathians are cold, with the yearly average air temperature of $3^{\circ} \mathrm{C}$ at Cozia $(1577 \mathrm{~m}), 0.2^{\circ} \mathrm{C}$ at Bâlea-Lake $(2038 \mathrm{~m}),-0.5^{\circ} \mathrm{C}$ at Țarcu $(2180 \mathrm{~m})$ and $-2.6^{\circ} \mathrm{C}$ at $\mathrm{Omu}(2505 \mathrm{~m})$, with an absolute minimum of $-38^{\circ} \mathrm{C}$. The isotherm of $3^{\circ} \mathrm{C}$ yearly average temperature indicating the lower limit of periglacial environment according to French (1996), lies around 1700 $\mathrm{m}$ a.s.1. From the Peltier diagramme the morphoclimatic systems to which the selected stations are affiliated are periglacial systems (Urdea, Sârbovan, 1995), with physical dominance for Omu and Bâlea-Lake, boreal system for Țarcu and temperate for Cozia (Fig. 2). The great number of frost days - 207,9 days/year at the Bâlea-Lake and 255 days/ year at the Omu Peak - and over 125 of the freeze-thaw cycles, and the great value of the gelivation coefficient for the main rocks (e.g. granite - 31, granodiorite - 36, gneiss - 35 , amphibolite -44) explains the efficiency of frost weathering. 
The yearly average precipitation is $844.2 \mathrm{~mm}$ at Cozia, $1246 \mathrm{~mm}$ at Bâlea-Lake, $1180 \mathrm{~mm}$ at Țarcu and $1280 \mathrm{~mm}$ at Omu. About $60-75 \%$ of the precipitation consists of snow, and the snow cover in the region lasts between 150-210 days a year. The thickness of the snow layer may range between 50 and $370 \mathrm{~cm}$ and is highly variable according to the wind action. The heavy rainstorms, occasionally in the late spring, in the summer and in the autumn (217.4 mm at 15.08.1993 at Țarcu, $195.6 \mathrm{~mm}$ at 3.06.1988 at Bâlea-Lake) appear to be responsible for the torrential erosion and debris-flow activity in the Southern Carpathians.

The high degree of hygrical continentality - T,arcu $-61^{\circ} 50^{\prime}$ and Omu - $63^{\circ} 50^{\prime}$ - favours the spread of a typical periglacial phenomenon such as rockglaciers (Urdea, 1993).

The timberline runs along generally between 1700 and $1850 \mathrm{~m}$, climbing up mainly on the southern exposed versants and climbing down on the northern exposed ones.

\section{PROBLEM ANALYSIS AND RESEARCH RESULTS}

Although the alpine area of the Southern Carpathians belongs to the periglacial and boreal morphoclimatic levels the present-day geomorphological processes are very complex and the periglacial processes are associated with the erosional ones.

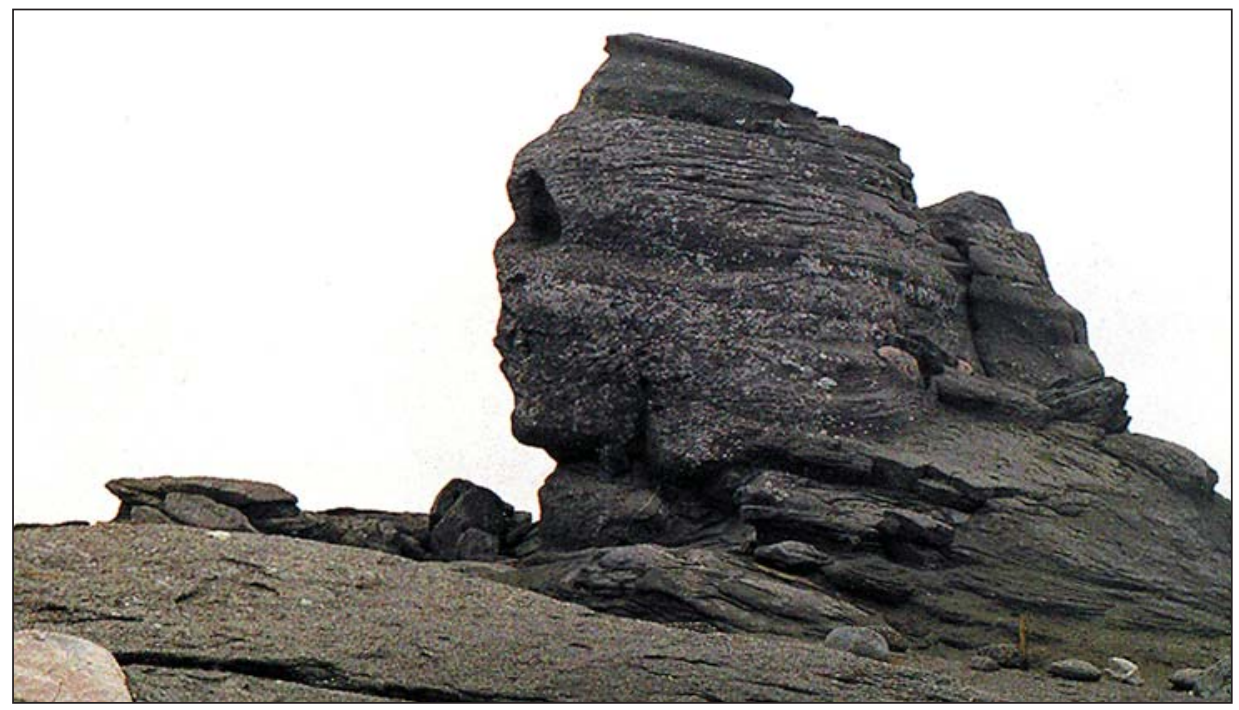

Fig. 3 The "Sphynx" an artefact megalith ?

Sl. 3. Sfinga-megali artefakt?

Speaking a time frame of the human impact that takes place in the alpine area of the Southern Carpathians we consider that they has been going on ever since Antiquity. An example is represented by the Roman castra of the second Dacian Roman War in the years 106-107 on the Auşelu Mountain at 1980 m a.s.l. and on the Comărnicelu Mountain at $1860 \mathrm{~m}$ a.s.l., with typical ditches and earthworks as well as the road connecting them, 
Petru Urdea, Marcel Törok-Oance, Mircea Ardelean, Florin Vuia, Mircea Voiculescu - Geomorphological Aspects of the Human Impact in the Alpine Area of Southern Carpathians (Romania)

and we can move on to Dacia's capital, Sarmizegetusa Regia in the Orăştiei Mountains with well visible anthropogenic landforms even today.

It is not unimportant that there are opinions according to which in the Bucegi Mountains in the Babele - Sphynx area and Gugu Mountain (Godeanu Mountains) there might have lived Zamolxys, the supreme God in the mythology of the Dacians. These sacred places for native populations, with typical forms like the Sphynx - with a controversial origin, natural (periglacial eolization and weathering) or an artefact megalith (Fig. 3) -, were a pilgrimage area for a long time, with geomorphologic consequences, connected with the destruction of vegetation layer, which favours the acceleration of erosion processes, and, of course, the appearance of characteristic landforms.

Ever since then and during the whole Middle Ages the alpine area of the Southern Carpathians has been included in the economic circuit thanks to its pastures, proof thereof being the fact that in the medieval documents, near the villages' territories (landowner) one also mentioned the mountains they owned including the sheepfolds and pathways (Urdea, 1983). These pathways are characteristic of the entire mountain area and are known as "plaiuri". We must notify that from the beginning of organised mountain tourism and appearance of the first mountain chalets - due of the initiative of Transylvanian Carpathians Association (,,Siebenbürgische Karpathen Verein”) in 1881 , the tourist pathways have been laid out according to these old shepherd pathways.

The construction of the roads in the alpine area is by far the most dangerous way of intervention in the mountain landscape. The most typical case is the one of the Transfăgărăşan Road (Fig. 4). This road was built between 10. 03. 1970 and 20.09.1974 and over 3.8 millions $\mathrm{m}^{3}$ of material were excavated: $212000 \mathrm{~m}^{3}$ of hard rocks, $150000 \mathrm{~m}^{3}$ of berms, embankments and ramps in unconsolidated materials and one built an $887 \mathrm{~m}$ long tunnel (Urdea, 1999).

Fig. 4 Topographical aspects of "Transfăgărăşan" Road in the Bâlea Area.

Sl. 4. Topografski aspekti Transfagaraške ceste u regiji Balea

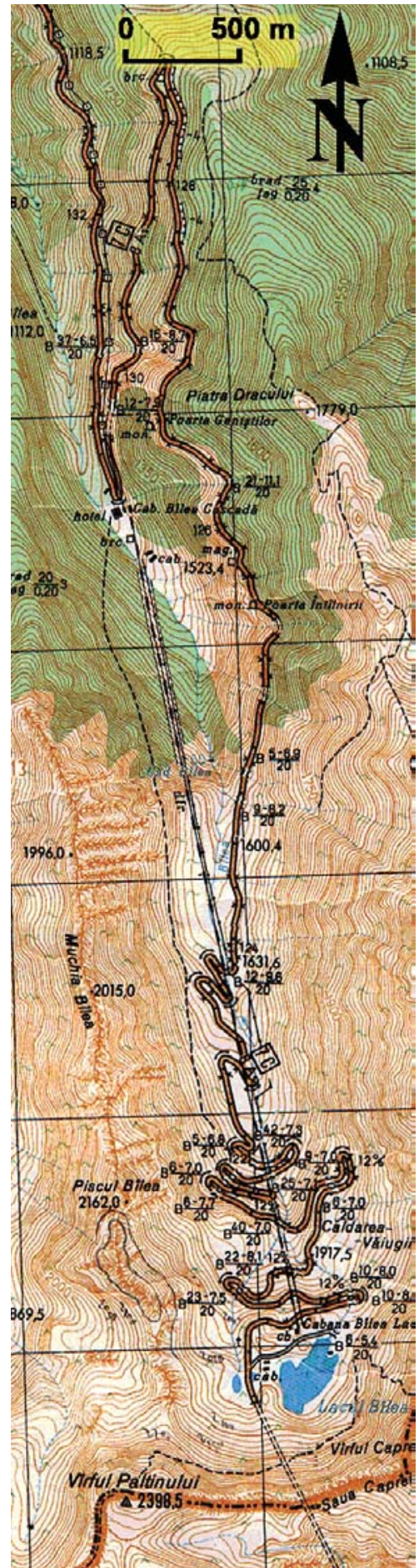


Beside the Transfăgărăşan Road we should mention the more poorly laid out roads - and due to these characteristics they are most vulnerable to the activity of the weathering and erosion agents -, accessible only to the carriages, tractors and off road vehicles in the alpine area of the Transylvanian Alps, with the total length of $230 \mathrm{~km}$, present in:

A. Bucegi Mts.: 1. Sinaia - Dichiu Saddle - Cocora Saddle (1945 m) - Babele Chalet (2200 m) - Coştila Mt. (2490 m) - 18 km;

2. Cocora Saddle (1945 m) - Piatra Arsă Chalet (1950 m) - Călugărului Saddle - 3 km;

3. Babele Chalet (2200 m) - Ciocârlia Mt (2043 m) - Călugărului Saddle - Carp Valley - $7.2 \mathrm{~km}$;

B. Leaota Mts.: 1. Bădeanca Valley - Romanescu Mt. - Tâncava Mt. (1750 m) - Leaota Mt. - Răteiu Saddle (1990 m) - 10 km;

C. Făgăraş Mts.: 1. Rucăr - Țefeleica Mt. (1560 m) - Găinațul Mare (1820 m) - 6 km;

2. Căpățâneni Ungureni - Zănoaga (1650 m) - Țuica Mt. (1970 m) - Jepii de Sus Mt. (2050 m) - 17 km;

3. Slatina - Malița Mt. (1960 m) - Gruişorul Mt (2010 m) - Lespezile Mt. (1980), Furfuescu Mt. - 27 km;

4. Malița - Cernatu Saddle - Preotesele Mt. (2010 m) - Drăghina Mt. (1930 m) - 16 km;

5. Capra valley - Fundu Caprei $-2.5 \mathrm{~km}$.

D. Cozia Mts.: Sălătruc - Babolea Mt. - Cozia Peak (1573 m) - 2.7 km;

E· Căpățânii Mts.: 1. Polovragi - Curmătura Oltețului (1620 m) - Petrimanu - 2 km;

2. Curmătura Oltețului (1620 m) - Negovanu Mt. (1910 m) - 4.7 km;

3. Romanii de Sus - Valeanu Mt. (1550 m) - 4.5 km;

4. Romanii de Sus - Roman Peak (1740 m) - Piatra Roşie Mt. 1820 m) - 9.2 km;

F. Parâng Mts.: 1. „Transalpina”, or Ferdinad's Road”, Novaci - Sebeş: Corneşu Mare (1460 m) - Rânca (1600 m) - Păpuşa Mt. - (2000 m) - Dengheru Mt. (2070 m) - Urdele Saddle (2145 m) - Cărbunele Mt. - (2110 m) - Ştefanu Mt. (1900 m) - La Căşerie (1580 m) - Obârşia Lotrului - 29 km;

G.Latoriței Mts.: Ştefanu Mt. (1900 m) - Puru Mt. (1940 m) - Frătoşteanu Mt. (1960 m) - Ştevia Mt. - 30 km;

H.Țarcu Mts. \& Muntele Mic: 1. Muntele Mic - 6.5 km;

2. Cuntu (1460 m) - Țarcu Peak (2190 m) - 6.1 km;

I. Vâlcan Mts.: 1. „Mihai Viteazul Road”, Schela - Vulcan: Zănoaga Mt. (1475 m) - Vâlcan Saddle (1621 m) - Dâmbul Caşilor (1480 m) - 8.2 km;

2. Vâlcan Saddle (1621 m) - Dumitra Mt. (1633 m) - Cândetu Mt. (1548 m) - 5.8 km;

3. „Drumul Neamțului” (,German’s Road”), Bâlta - Câmpul lui Neag - Gura Plaiului (1490 m) - Dâmbu Mt. - Arcanu Mt. (1658 m) - Stâna Arcanu - 3.7 km. 
Petru Urdea, Marcel Törok-Oance, Mircea Ardelean, Florin Vuia, Mircea Voiculescu - Geomorphological Aspects of the Human Impact in the Alpine Area of Southern Carpathians (Romania)

Some of these are ancient commercial roads that were connections between Transylvania and Walachia such as "Drumul Neamţului" (German's Road) and Mihai Viteazu's Road in the Vâlcan Mountains. Others were military strategic roads, built before the First World War (Ferdinand's Road) and continued in the Inter-World War period. Also, other roads were built in the communist period like access roads to the sheepfolds with a large number of cattle of the agricultural cooperatives. Therefore one can determine the known geomorphological aspects, connected with erosional features, like those in area of Lespezile, Podeanu, Preotesele and Țuica Mountain (Făgăraş Mountains). We must mention that in the area of the upper end of pasture roads, the upper timberline descends because the deforestation is a common and "normal" human effect in the mountain landscape.

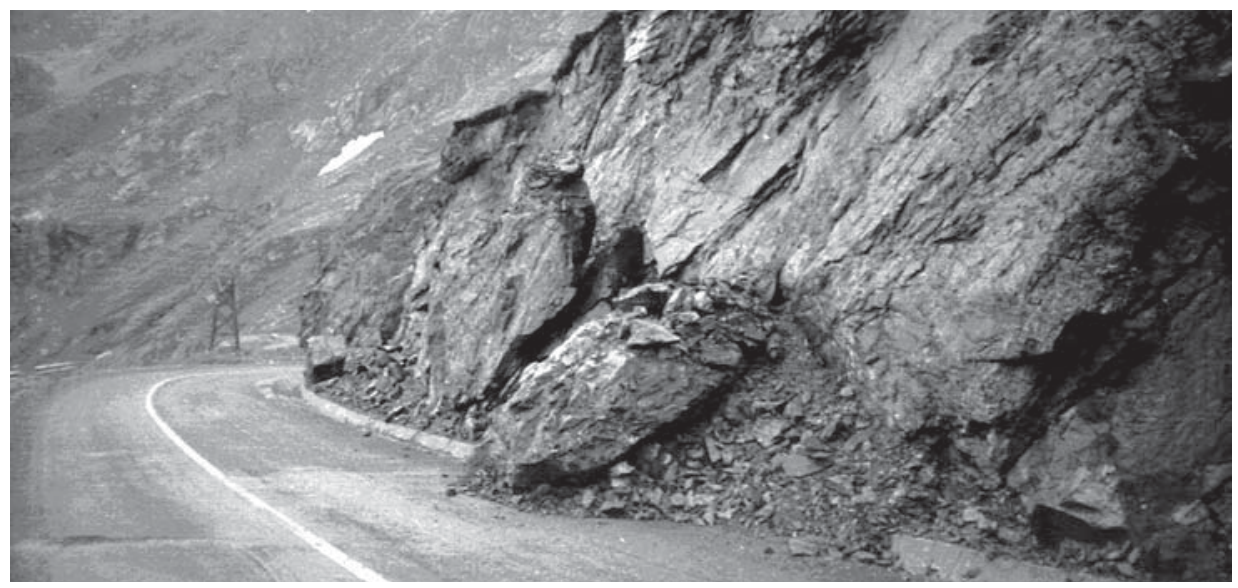

Fig. 5 New cliff, falling blocks and debris on the "Transfăgărăşan" road, favoured by the schistosity planes in a typical metamorphic structure

Sl. 5. Novooblikovani strmac, blokovi i kršje uz Transfagarašku cestu duž pukotina u tipičnoj metamorfnoj strukturi

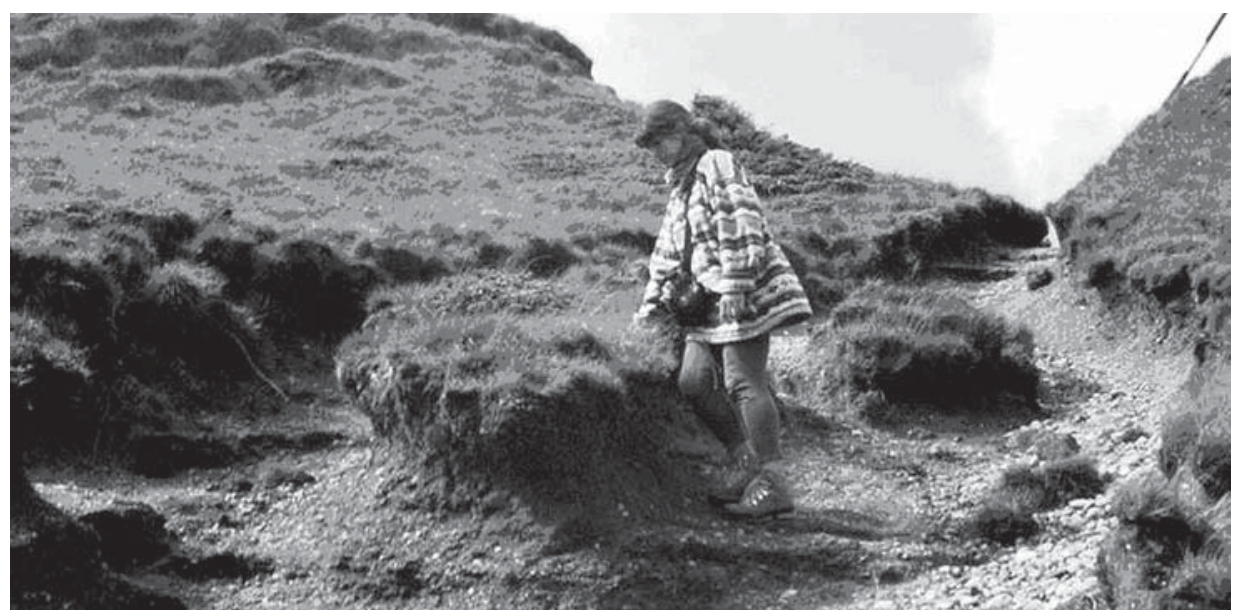

Fig. 6 Gully and ravines in conglomerate area of the Bucegi Mountains

Sl. 6. Jaruge i vododerine u konglomeratima planine Bucegi 
The construction of these roads has altered the slope profile and new, anthropogenic scarps have appeared. This new geomorphologic situation, associated with the vibrations induced by the traffic, favours frost weathering, rock falling (Fig. 5) and rolling - with the emergence of talus cones, talus scree and versants of frost-crumbled blocks -, and of course, the vertical erosion, very typical of the conglomerate area in the Bucegi Mountains (Fig. 6).

These masses of debris are in a disturbed balance, being easily dislodged by avalanches and thus by the debris-flow phenomenon. For example, as a result of our field measurements in the 2000- 2003 period, we have discovered that between $0.5-3.5 \mathrm{~m}^{3} /$ year of debris appears per linear metre of the newly created scarp, compared to $0.1-0.7 \mathrm{~m}^{3} /$ year in the natural slope conditions.

For the debris flow phenomenon an abundance of water is required and certain conditions are particularly favourable: a). high rainfall intensity of long duration; b). rainfall on thawing snow pack; c). small drainage basins with steep slopes in which rainfall intensity is uniformly high and runoff is rapid (Van Steijn, 1988; Selby, 1993). The debris flows research area are small-scale hill-slope flows, debris cones connected to avalanches pathways (Urdea et al., 2004), according to the classification given by literature (Rapp, 1981; Takahashi, 1981). The importance of these phenomena may be measured by the damage they have caused, especially on glacial cirques and valley floors and lower cirques and valley sides. In the Transfăgărăşan area the anti-avalanche constructions have changed the direction of the water drainage lines, initiating intensive debris flows in the middle and lower part of the slopes.

In the case of the unasphalted roads built in the embankment and/or partial embankment, their ramp is affected by the slope processes. For those cut into the rock, the weathering, falling and rolling associated with the accumulations represent the characteristic processes. For those cut into the slope deposits, mantle-rock and in the soil, the rain, gully and torrential erosion are partially present processes (Niculescu, 1987). The furrows created by the wheels of the vehicles represent the main lines of initiation and then accentuation of the pluvial erosion and gully development. Also the growth of tourist activity together with people tracking down the tourist pathways has caused the herbaceous vegetation to disappear in these areas, which has further initiated and intensified the gullying and erosion processes. An eloquent example is the situation of the Bucegi Plateau where the non-observance of the tourist routes have determined the appearance of many pathways affected by severe erosion processes (Fig. 6). Here, in some areas the density of disorganised pathways reaches $15 \mathrm{~km} / \mathrm{km}^{2}$.

Over the last 10 years on the mountain roads and paths in the western part of the Southern Carpathians, especially in the Muntele Mic - Țarcu Mountains, the degradation has increased due to a new sport in Romania: mountain off road motorcycling and Enduromania contests.

We also mention the traces of the trenches dug out during the warfare WWI operations that took place in the Tulişa Mountains (in the area Curmătura Tulişa - Coasta Laturii - Oboroca), in the Vâlcan Mountains (in the areas Coarnele, Şigleu, Rostovanu, Arcanul), in the Lotru Mountains (in Robul-Murgaşul-Gorganul) area, and in the Făgăraş Mountains 
Petru Urdea, Marcel Törok-Oance, Mircea Ardelean, Florin Vuia, Mircea Voiculescu - Geomorphological Aspects of the Human Impact in the Alpine Area of Southern Carpathians (Romania)

(in Budislavul-Suru-Mâzgavul area and Călugărul-Fața Sf. Ilie-Comarnic area), or in areas where at present military training of troops is taking place, like in Muntele Mic, Parângu Mic, Bucegi Plateau areas etc.

Even pasturage is very old, the use of the alpine lawns, normally does not have major effects on the geomorphological landscape. The intensive and irrational pasture activities associated with bush vegetation burning favour the acceleration of the erosion processes (sheet erosion, rill erosion, gullying and torrential erosion), and, of course, the appearance of characteristic biogenic landforms, like cattle tracks. Land degradation is increased especially in the area of the sheepfolds (Fig. 7), where an impression of the magnitude of this phenomenon one can have considering the density of the sheepfolds placed in the alpine area (Table 1).

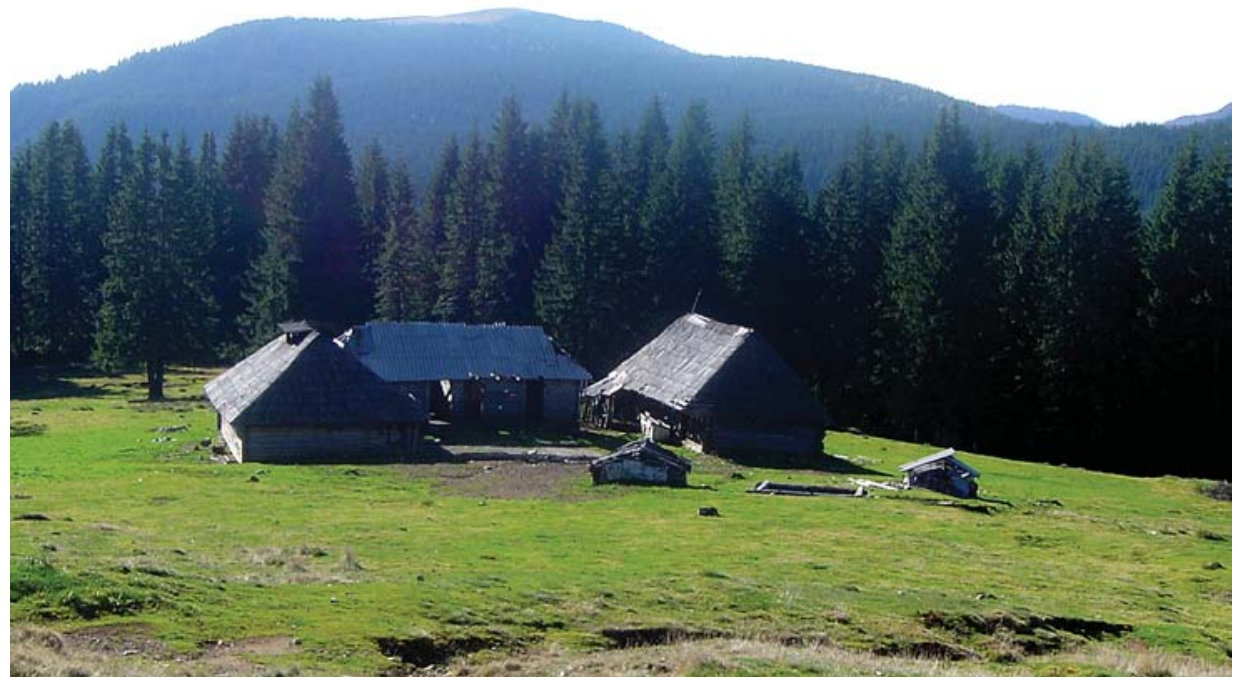

Fig. 7 The sheepfold Rodeanu in Căpătânii Mountains (photo Al. Onaca )

Sl. 7. Tor Rodean $u$ Capatanii

Table 1 The density of the sheepfolds in the alpine pastures

Tab. 1. Gustoća torova u odnosu na površinu planinskih pašnjaka

\begin{tabular}{|c|c|c|c|c|}
\hline $\begin{array}{c}\text { The mountain } \\
\text { range }\end{array}$ & $\begin{array}{c}\text { Alpine } \\
\text { pastures } \\
\text { surface } \\
\left(\mathbf{k m}^{2}\right)\end{array}$ & $\begin{array}{c}\text { Number of } \\
\text { sheepfolds } \\
\text { in the alpine } \\
\text { pastures }\end{array}$ & $\begin{array}{c}\text { The density of the } \\
\text { sheepfolds in the alpine } \\
\text { pastures } \\
\left.\text { (nr. of sheepfolds/km } \mathbf{k m}^{2}\right)\end{array}$ & $\begin{array}{c}\text { The surface } \\
\text { of alpine } \\
\text { pastures for } \\
\text { a sheepfold } \\
\left(\mathbf{k m}^{\mathbf{2}}\right)\end{array}$ \\
\hline \multicolumn{5}{|c|}{ RETEZAT-GODEANU RANGE } \\
\hline Retezat & 128.4 & 25 & 0.19 & 5.136 \\
\hline Godeanu & 135.8 & 78 & 0.57 & 1.741 \\
\hline Cernei & 37.957 & 18 & 0.474 & 2.108 \\
\hline
\end{tabular}




\begin{tabular}{|c|c|c|c|c|}
\hline $\begin{array}{c}\text { The mountain } \\
\text { range }\end{array}$ & $\begin{array}{c}\text { Alpine } \\
\text { pastures } \\
\text { surface } \\
\left(\mathbf{k m}^{2}\right)\end{array}$ & $\begin{array}{c}\text { Number of } \\
\text { sheepfolds } \\
\text { in the alpine } \\
\text { pastures }\end{array}$ & $\begin{array}{c}\text { The density of the } \\
\text { sheepfolds in the alpine } \\
\text { pastures } \\
\text { (nr. of sheepfolds } / \mathrm{km}^{2} \text { ) }\end{array}$ & $\begin{array}{l}\text { The surface } \\
\text { of alpine } \\
\text { pastures for } \\
\text { a sheepfold } \\
\left(\mathbf{k m}^{2}\right)\end{array}$ \\
\hline Țarcu & 122.5 & 83 & 0.67 & 1.475 \\
\hline Muntele Mic & 11.9 & 8 & 0.67 & 1.487 \\
\hline Tulişa & 19.6 & 16 & 0.81 & 1.225 \\
\hline Piule-Iorgovanu & 28.4 & 3 & 0.1 & 9.466 \\
\hline Vâlcan & 54.1 & 25 & 0.46 & 2.164 \\
\hline \multicolumn{5}{|c|}{ PARÂNG-LOTRU RANGE } \\
\hline Parâng & 167.215 & 71 & 0.424 & 2.355 \\
\hline Latorița & 34.029 & 29 & 0.852 & 1.173 \\
\hline Căpăţânii & 69.893 & 67 & 0.958 & 1.043 \\
\hline Lotru & 124.522 & 98 & 0.787 & 1.270 \\
\hline Cindrel & 73.215 & 37 & 0.505 & 1.978 \\
\hline Şureanu & 64.916 & 47 & 0.724 & 1.381 \\
\hline \multicolumn{5}{|c|}{ FĂGĂRAŞ RANGE } \\
\hline Făgăraş & 438.6 & 92 & 0.21 & 4.767 \\
\hline Iezer & 89.85 & 27 & 0.3 & 3.327 \\
\hline Cozia & 1.31 & 4 & 3.07 & 0.327 \\
\hline \multicolumn{5}{|c|}{ BUCEGI RANGE } \\
\hline Bucegi & 66.23 & 32 & 0.48 & 2.069 \\
\hline Leaota & 38.9 & 23 & 0.6 & 1.691 \\
\hline
\end{tabular}

The highest values are 0,81 sheepfolds $/ \mathrm{km} 2$ in the Tulişa mountain range, 0,85 sheepfolds $/ \mathrm{km}^{2}$ in the Latorița mountain range and 0,95 sheepfolds $/ \mathrm{km} 2$ in the Căpăţânii mountain range, in contrast with low values in mountain areas situated in protected spaces, like the Retezat National Park, with 0,19 sheepfolds $/ \mathrm{km} 2$. A true image of land degradation intensity in sheepfolds area is possible if we take into account the fact that many sheepfolds are very old in the same area - from the Middle Age times (Urdea, 1983 ) - and, in a relatively small area that there are many buildings - some out-houses -, like a small hamlet.

If in the mountain areas with a low and moderate tourist inflow and with a normal pastoral activity like in the Godeanu, Şureanu, Lotru, Leaota, Cernei, Vâlcan and Căpățânii Mountains the effects of the human geomorphological impact are insignificant, in the Bucegi Mountains (the mountains with the highest tourist pressure) the geomorphological landscape bears the marks of strong human intervention.

The mining activities, are not present except in the Făgăraş Mountains, in Capra Valley, Buda Valley and Podeanu Mountain, with exploitation galleries, spoil banks and access roads made in the communist period of the $80 \mathrm{~s}$, years of searching for resources in order to achieve "the economic independence of Romania". 
Petru Urdea, Marcel Törok-Oance, Mircea Ardelean, Florin Vuia, Mircea Voiculescu - Geomorphological Aspects of the Human Impact in the Alpine Area of Southern Carpathians (Romania)

CHGMCAL WEATHIORNNG

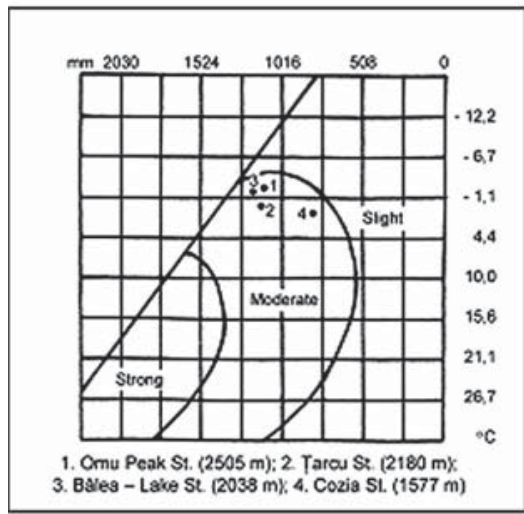

MASS MO VEMMIN T

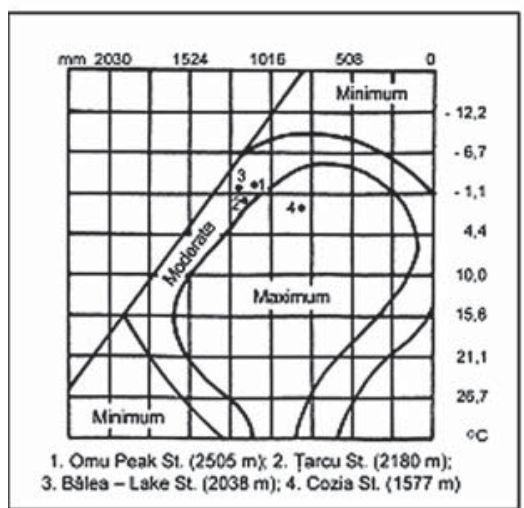

GELIFRACTION

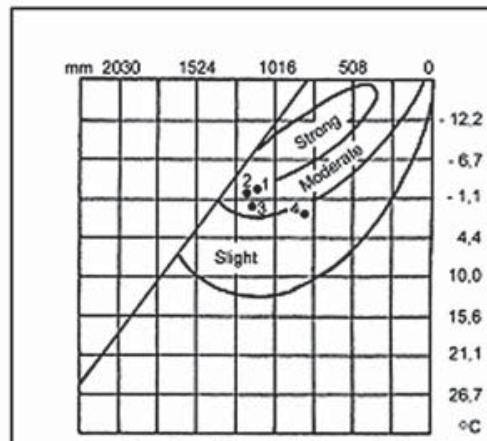

1. Omu Peak St. $(2505 \mathrm{~m}): 2$. Tarcu St. $\{2180 \mathrm{~m}$ : 3. Balea - Lake St. (2038 m); 4 . Cozia St. (1577 m)

FLUVIAL PROCESSES

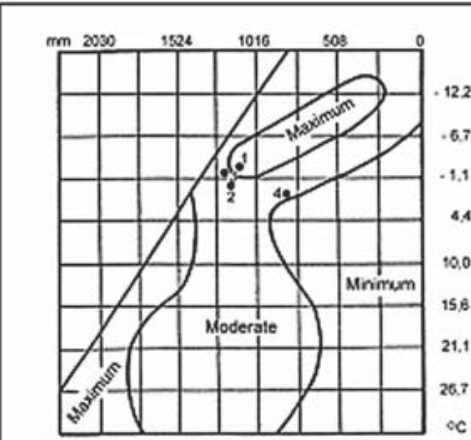

1. Omu Peak St $(2505 \mathrm{~m}) ; 2$. Tarcu St. $(2180 \mathrm{~m})$ :

3. Balea - Lake St. (2038 m); 4. Cozia St. (1577 m)

WT.A THFRTN

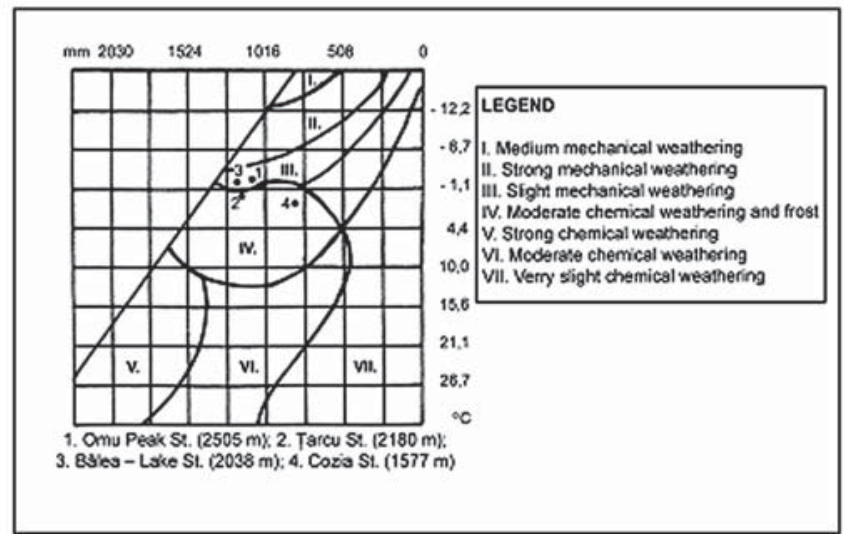

Fig. 8 Morphodynamic potential of Southern Carpathians in the Peltier diagrammes

Sl. 8. Morfodinamički potencijal Južnih Karpata prema Peltierovim dijagramima 
Intense human activity often determines an acceleration of the gully and torrential erosion and raindrop erosion impact which leaves its mark on the landscape (ravines, gullies, torrents, small badlands) as it happens in the alpine area of the Bucegi Mountains. The destruction of the vegetal layer making for the installation and then the acceleration of torrential erosion. One can see that the gully erosion and torrential processes set in along the tourist paths (Fig. 6) and along the non-conventional roads. Within the Retezat Mountains, due to the regulations imposed by the existence of The Retezat National Park, first national park of Romania in 1935, the human impact - including the one from the geomorphological point of view - is low, being present only along the tourist paths and around the sheepfolds.

One should not forget the fact that the geomorphological processes, characteristic of the alpine area, intensified and accelerated by the human factor overlap with a significant morphodynamic potential as it has been suggested in the Peltier diagrammes (Fig. 8). We find that the weathering, gelifraction, chemical weathering, mass movement, gullying, fluvial and rill erosion are moderate and strong.

Otherwise, the processes associated with human intervention in the alpine area are considered as major risk phenomena typical of the Carpathian Mountains (Bălteanu, 1997).

\section{CONCLUSIONS}

As a result of the analysis of the human geomorphologic impact on the geomorphological landscape of the alpine area of the Southern Carpathians, we conclude that the impact is strong and with a tendency of generalization in the Bucegi Mountains and it has an insular character and a tentacular one in the area of the sheepfolds and chalets, as well as of the alpine roads, of the intensely used tourist paths.

Knowing the alpine area of the Transylvanian Alps very well, we conclude that the building of the roads in the alpine area is by far the most dangerous way of human intervention in the geomorphological landscape. An instructive example is the building of the Transfăgărăşan road, where in their connected area the morphogenetic conditions were changed, with the emergence of new cliffs. This situation associated with the vibrations induced by the traffic, favours frost weathering, rock falling and rolling - with the appearance of talus cones and versants of frost-crumbled blocks. In the area with intensive and chaotic tourist paths network and also in the intensive pasturage areas, which bring about the destruction of the bush and herbaceous vegetation, vertical erosion associated with ravines, gullies and torrents, is very typical of the conglomerate area in the Bucegi Mountains and also of the area with thick soils and soft rocks.

Acknowledgement. The investigations were financially supported by CNCSIS as part of the Research Grant 828/4 (2000) and 256/8 (2002). Many thanks go to Prof. Dr. Andrija Bognar and Dr. Nenad Buzjak for the constructively reviewed previous version of this paper. 
Petru Urdea, Marcel Törok-Oance, Mircea Ardelean, Florin Vuia, Mircea Voiculescu - Geomorphological Aspects of the Human Impact in the Alpine Area of Southern Carpathians (Romania)

\title{
REFERENCES
}

Bălteanu, D., 1997: Romania, in Embleton, C., Embleton-Hamann(eds.) „Geomorphological hazards of Europe”, Amsterdam-Laussane-New York-Oxford-Tokyo, 409-427.

French, H.M., 1996: The Periglacial Environment, (Second edition), Longman, Harlow, 341 p.

Niculescu, G., 1987: Acțiunea proceselor geomorfologice asupra drumurilor carosabile din Carpații Meridionali, St. cerc. geol., geofiz., geogr., Geografie, XXXIV, 32-39.

Rapp, A., 1981: Slope processes in high latitude mountains, Progress in Physical Geography, 10, 1, 53-68.

Selby, M.J., 1993: Hillslope materials and processes, (Second edition), Oxford University Press, 451 p.

Takahashi, T., 1981: Debris flow, Annual Review of fluid mechanics, 13, 57-77.

Urdea, P., 1983: Munții Fãgãraşului în documente din secolul al XVII-lea, Lucr. Sem. geogr. „D. Cantemir”, Univ. “Al. I. Cuza” Iaşi, 3, 133-141.

Urdea, P., 1992: Rock glaciers and periglacial phenomena in the Romanian Carpathians, Permafrost and Periglacial Processes, 3, 267-273.

Urdea, P., 1995: Quelques considérations concernant des formations de pente dans Les Carpates Méridionales, Permafrost and Periglacial Processes, 6, 195-206.

Urdea, P., 1999: The geomorphological risk in the Transfăgărăşan Higway area, Studia Geomorphologica Carpato-Balcanica, XXXIV, 113-122.

Urdea, P., 2000: Munții Retezat. Studiu geomorfologic, Edit. Academiei Române, Bucureşti, 272 p.

Urdea, P., Sârbovan, C., 1995: Some considerations concerning morphoclimatic conditions of the Romanian Carpathians, Acta Climatologica Universitatis Szegediensis, 28-29, 23-40.

Urdea, P., Vuia, F., Ardelean, M., Voiculescu, M., Törok-Oance, M., 2004. Investigation on some present-day geomorphological processes in the alpine area of the Southern Carpathians (Transylvanian Alps), Geomorphologia Slovaca, 4, 1, 5-11.

Van Steijn, H. 1988: Debris flows involved in the development of Pleistocene stratified slope deposits, Zeitschrift für Geomorphologie, Supplementband, 71, 45-58.

\section{SAŽETAK}

\section{Geomorfološki aspekt antropogenih utjecaja u gorskom području Južnih Karpata (Rumunjska)}

\author{
Petru Urdea, Marcel Törok-Oance, Mircea Ardelean, \\ Florin Vuia, Mircea Voiculescu
}

Cilj članka jest prezentirati geomorfološki aspekt antropogenih utjecaja u gorskim područjima s naglaskom na utjecaje u najreprezentativnijoj gorskoj cjelini Rumunjske - Južnim Karpatima ili Transilvanskim Alpama. To je najviši dio rumunjskih Karpata s četrnaest vrhova viših od $2500 \mathrm{~m}$. Među njima je najviši Moldoveanu (2544 m, Fagaraške planine). Deset posto površine nalazi se u visinskom pojasu iznad $2000 \mathrm{~m} \mathrm{n}$. v. Kao metode istraživanja upotrijebljene su inventarizacija i 
geomorfološko kartiranje područja zahvaćenih antropogenim utjecajima te njihova kvantifikacija (posebno produkcije rastrošenog materijala, razvoja mreže jaruga i procjene površine zahvaćene intenzivnim gaženjem na pašnjacima). Utvrđivanje pojedinih važnih povijesnih razdoblja s jačim antropogenim utjecajima bilo je moguće na temelju istraživanja povijesnih izvora i arheoloških istraživanja.

Za pravilno razumijevanje morfogenetskih posebnosti gorskih područja rumunjskih Karpata bitna je činjenica da izoterma srednje godišnje temperature zraka $3{ }^{\circ} \mathrm{C}$, koja po Frenchu (1996) označuje donju granicu preiglacijalnog okoliša, leži na oko $1700 \mathrm{~m} \mathrm{n}$. m. Peltierovi dijagrami jasno upućuju na morfološke sustave kojima pripadaju odabrane meteorološke postaje: Oma (2505 m) i jezero Balea $(2038 \mathrm{~m})$ periglacijalnome, Tarcu $(2180 \mathrm{~m})$ borealnome i Cozia $(1577 \mathrm{~m})$ umjerenome. Šumska granica nalazi se između 1700 i $1850 \mathrm{~m} \mathrm{n}$. v., ovisno o ekspoziciji padina.

Po našemu mišljenju, gradnja prometnica daleko je najopasnija intervencija čovjeka u gorskom krajoliku. Stoga je u članku prezentirano stanje oko prometnica s geomorfološkoga gledišta s posebnim naglaskom na Transfagarašku cestu. Gradnjom prometnica izmijenjen je profil padina i javljaju se novi strmci, čime se mijenjaju morfogenetski uvjeti. Takvo stanje, povezano s vibracijama izazvanima prometom, favorizira kriofrakcijski proces i padinske procese (osipanje i odronjavanje) $\mathrm{s}$ akumulacijom padinskog materijala i vertikalnom erozijom tipičnom za područja planine Bucegi građene od konglomerata te za područja građena od mekših stijena i s tankim slojem tla.

Dobar primjer geomorfološke transformacije krajolika jest gradnja Transfagaraške ceste od 10. ožujka 1970. do 20. rujna 1974. To je bio opsežan posao kojime je iskopano oko tri milijuna $\mathrm{m}^{3}$ materijala, od čega $212.000 \mathrm{~m}^{3}$ kamenja te $150.000 \mathrm{~m}^{3}$ nasipa i rampi u nekonsolidiranim materijalima. Izgrađen je i tunel dug $887 \mathrm{~m}$. Tragovi kotača vozila predstavljaju glavne linije aktiviranja pluvijalne erozije i jaruženja. Porast turističkih posjeta izazvao je povlačenje vegetacije u pojedinim područjima, što je postupno uzrokovalo jačanje erozijskih procesa. Izrazit je primjer za to plato Bucegi, gdje su brojne neplanirane pješačke staze utjecale na snažnu linijsku eroziju. U pojedinim područjima gustoća takvih staza doseže $15 \mathrm{~km} / \mathrm{km}^{2}$.

Intenzivno neracionalno iskorištavanje pašnjaka karakterizirano uništavanjem livada i paljenjem grmolike vegetacije pospješuje erozijske procese i pojavu karakterističnih biogenih reljefnih oblika duž stočarskih staza. Degradacija tla naglašena je na područjima torova, ovisno o njihovoj gustoći na jedinici površine.

S morfodinamičke točke gledišta zaključujemo da su u planinama Bucegi snažni antropogeni utjecaji, za razliku od planina Retezat, gdje je stanje regulirano zbog postojanja nacionalnog parka, pa su utjecaji puno slabiji. Tamo su oni lokalnoga karaktera, koncentrirani na područja s torovima i kolibama. Jaruženje je najsnažnije duž turističkih pješačkih staza i prometnica.

Petru Urdea, Marcel Törok-Oance, Mircea Ardelean, Florin Vuia, Mircea Voiculescu

West University of Timişoara

Department of Geography

B-dul V. Pârvan, Nr. 4

300223 - Timişoara, Romania 